\title{
The importance of commercial credit for business in Portugal
}

\author{
António José dos Santos Morão Lourenço, Alexandre Gonçalves Governo, ${ }^{2}$ \\ ARIANA INÊS GONÇALVES LEAL ${ }^{3}$ \\ ${ }^{1} \mathrm{PhD}$ in Financial Management, School of Management and Technology, \\ Santarem Polytechnic Institute, Portugal \\ e-mail: antonio.lourenco@esg.ipsantarem.pt \\ ${ }^{2}$ Student in Accounting and Finance Master, School of Management and Technology, \\ Santarem Polytechnic Institute, Portugal \\ e-mail: alexgoverno@hotmail.com \\ ${ }^{3}$ Student in Accounting and Finance Master, School of Management and Technology, \\ Santarem Polytechnic Institute, Portugal \\ e-mail: ariana-leal_12@hotmail.com
}

KEYWORDS commercial credit, companies, trade, financing, capital structure

ABstract Purpose - this work aims to study the non-financial credit granted to customers by Portuguese companies, when this is used as a form of financing. Here, we intend to analyze the impact that this type of credit (commercial credit) may have on the capital structure of a company, because, receiving such credit, can be seen sometimes to overlap with financial credit (banks).

Methodology - we will present our analysis in two phases: in the first, we will distinguish between large companies and small and medium-sized enterprises, and later we will make a more global analysis. This way, in addition obtaining information into the ways business finance themselves, we can also get a sense of the main motivations and determinants of this type of credit through an analysis using the panel data methodology.

Findings - this study shows us some interesting realities. Among others, it is possible to highlight the fact that large companies are the ones that most appeal to commercial credit, and the evidence that the companies with greater ability to access the capital markets, higher gross margin and higher sales volume grant more trade credit than the others.

Value - one of the most valuable points of this work is that the data was collected during the current economic crisis. It provides insight into how companies responded to this and this is reflected in the data and the conclusions drawn. The current financial situation of crisis, together with the difficulty of access to loans, as well as the pressure from shareholders of the companies to obtain results, are some of the factors that were focused in this study.

\section{Znaczenie kredytu kupieckiego w finansowaniu działalności gospodarczej na przykładzie Portugalii \\ SŁoWA KLUCZOWE kredyt kupiecki, firmy, handel, finansowanie, struktura kapitału \\ Cel-identyfikacja i ocena wpływu kredytu kupieckiego na strukturę kapitału w przedsiębiorstwie. Metodyka badania - badania przeprowadzono i przedstawiono w dwóch ujęciach. W pierwszym dokonano analizy z podziałem populacji na duże oraz małe i średnie przedsiębiorstwa. Następnie wyniki uogólniono, dzięki czemu sformułowano wnioski dotyczące sposobów finansowania przed-}


siębiorstw oraz wskazano motywacje i determinanty wykorzystania kredytu kupieckiego w działalności badanych jednostek.

Wynik - przeprowadzone badania stanowią podstawę dla sfomułowania kilku interesujących spostrzeżeń - stwierdzono np., że duże przedsiębiorstwa wykazują największe zainteresowanie kredytem kupieckim, zaś najwięcej kredytów kupieckich udostępniają podmioty osiągające wysoką marżę brutto i dużą wielkość sprzedaży.

Wartość - jednym z najbardziej wartościowych walorów artykułu jest to, że dane zostały zgromadzone podczas obecnego kryzysu gospodarczego, dzięki czemu badania ilustrują zachowania przedsiębiorstw w warunkach turbulentnego otoczenia. Dodatkowo, w ramach badania uwzględniono także takie czynniki, jak trudności w dostępie do kredytów bankowych i presję strony akcjonariuszy spółek na uzyskanie wyników.

\section{Introduction}

Nowadays, as the country is still trying to overcome a period of economic crisis, financial difficulties are very common among most companies.

The difficulty in access to bank credit is a very important hindrance factor in the development of many companies. This situation has led companies to look for other means of financing their development, such as the use of extension of payment terms with suppliers, which has become an increasingly important aspect to consider. In this study we will then look at this alternative option: the use of commercial credit instead of the credit resource from financial institutions.

This subject is of interest, not only in the study of the manner in which companies try to finance themselves, but also in their motives and determining factors that lead them to finance themselves in a certain way.

Although this type of analysis may have already been previously treated by other authors (few, however, as we can see, for the few studies in this field), we consider this study relevant to the literature for two main reasons, first its timeliness of the data and second because of its analysis of variables that had not been analyzed previously.

This work is organized in the following manner: we begin with a brief literature review, where we refer to a variety of authors whom we have used to form the basis of the hypotheses presented simultaneously. This is followed by the data-based approach we used. We indicate the period under study as well as the variables that were considered in the same period, and constitute the model.

After this, we present the results that allow us to verify the hypotheses formulated, as well as the limitations that our work has expressed and we weave some final considerations about the same, indicating some other potential studies to develop.

\section{Contextual framework}

We begin with a quote from Brennan et al. (1988), which represents some of the basis of our work "in addition to financing through financial institutions, trade credit may also be a funding source, especially for companies with limited access to bank financing." 
According to the first model developed by Modigliani and Miller (1958), in a balanced situation and perfect capital market environment, "the weighted average cost of capital and the company's value are independent of the company's financing structure." Later (1963) the authors were to readjust their model, taking into consideration the existence of taxes, arguing that 'the value of the company is positively related to the level of debt, through the tax benefit associated with foreign capital." This theory is thus based on the existence of tax savings through the use of borrowed capital.

Other authors who have studied the subject were Serrasqueiro and Nunes (2008), who corroborate the model of MM, proving that "the tax effect is one of the basic factors in determining the capital structure."

On the other hand, Kashefi-Pour et al. (2010) developed studies on the concept of trade-off, proving "the existence of an optimal capital structure, achieved through the relationship between debt and equity, that allows balance the present value of tax benefits with financial insolvency costs."

However, MM's second model has been questioned by another, Myers (1984). This author suggests the pecking order approach where it was argued that there was "a preference hierarchy in the choice of funding sources", preferring the company to finance itself primarily with its own capital, second with external financing, and only in the last case by the issuing of new shares. Myers' proposals were subsequently confirmed by Serrasqueiro and Nunes (2008), Vieira and Novo (2010) and Vieira (2013). Currently, commercial credit has, as already mentioned, to be seen also as a form of business financing.

Van Der Wijst and Hol's studies (2002) have shown that this form of credit is on average $20 \%$ to $25 \%$ of total liabilities of European companies and that large companies (LC) grant, as a rule, more trade credit.

Garcia-Teruel and Martinez-Solano (2010), after the study of a sample of Small and Medium-sized European Enterprises (SME), found evidence that companies with higher credit resource facility were the same as those that grant more credit to their customers.

This theory was challenged by Ogawa et al. (2011), after the study of a group of Japanese SME, which concluded that small and medium-sized enterprises with more difficult access to credit were the most dependent on the commercial credit.

Following their studies listed above, Van Der Wijst and Hol (2002) also concluded that SMEs suffer from greater credit rationing, derived from their reduced ability to access bank financing, resulting in lower liquidity, which reflects lower guarantees for banks and higher volatility than large companies (LC).

Receiving commercial credit can also offer companies unexpected benefits. Biais and Gollier (1997) argue that the use of commercial credit can help companies to get bank financing, because "this alternative source of financing generates information about the credit quality of the companies which receive commercial credit and this information may be useful to financial institutions."

According to Schwartz (1974): "suppliers may have advantages over traditional lenders, when granting trade credit to their customers." This advantage is essentially derived from the fact that they know the true value of their customers better, having greater access to information about them, which allows greater control over these companies and a greater degree of security in 
the settlement of these claims. With this access to information between enterprises, in particular regarding their financial situation, there is a decrease in the asymmetry of information between suppliers and customers.

Ferris's studies (1981) show that the relationship between suppliers and customers still enables the former to control the actions of the latter, these being dependent on the supply of raw materials (which, when granted to customers, become a debt guarantee, which can be recovered in the possibility of non-payment).

The studies of Mian and Smith (1992); and Garcia-Teruel and Martínez-Solano (2010) also show that trade credit can lead to legal price discrimination, a situation that can be intensified, as illustrated by the research of Petersen and Rajan (1997), in the case of non-existence of potential customers substitutes. In such cases, the propensity to lend will increase as the gross margin of the company increases. The higher margins allow companies to finance their customers with a cost below the banking institutions and, therefore, can keep their customers in the long term (Bahillo, 2000).

According to Ferris (1981), "trade credit allows a reduction of transaction costs borne by the company, when paying in cash, and thus seen as a trade policy tool which contributes to better management of inventories", gaining special importance when we face high seasonal products, or look for rather uncertain markets, according to Bahillo (2000). This theory is further proven by Nilsen (2002) and Rodríguez-Rodríguez (2008), who verify a reduction of transaction costs with the granting of commercial credit.

Cheng and Pike (2003) also validate the theory that:

companies that sell goods whose quality can't be verified directly (as in the case of new products) have a tendency to grant more trade credit, allowing customers to check the quality of the products before the payment, reinforcing the company's image in the market,

contrary to what occurs with products whose sale is more frequent or that the benefits are already better known. It is expected then that turnover and the granting of commercial credit are two directly related factors.

\section{Methodology}

\subsection{Sample and data period}

For this study, we collected data from 60 non-financial companies, where 48 were LCs and 12 - SMEs.

The choice of non-financial companies arose from the nature of the study in question: as we intended to study the granting of commercial credit, we did not cover financial companies in the sample.

The companies chosen were mainly industrial companies; however, there were still some service sector firms, such as housing and health care companies.

The analysis was carried out over a period of six years, corresponding to the period dating from 2009 to 2014. 
The analysis paid particular attention to the fact that the data was collected during the current economic crisis. It provides insight into how companies responded to this and this is reflected in the data and the conclusions drawn.

\subsection{Research hypothesis and variables}

Based on the review of the literature, we formalized a set of hypotheses to be tested:

H1: Companies with greater financial credit access capacity grant more trade credit to their customers.

H2: Large companies grant more trade credit than small and medium enterprises.

H3: Companies which have higher gross operating margins grant more trade credit.

H4: Companies that use a higher assets rotation grant more trade credit, and less transaction costs.

To accomplish this study and test our hypotheses, and in order to better understand our dependent variable, defined here as the granted commercial credit (GCC) (Customers/Total Assets), we define a set of explanatory or independent variables.

In order to be able to understand the capacity of access to credit by companies and the cost of this access, we used the Cost of Debt (CDEBT), presented as the relationship between financial expenses and the total liabilities, less current accounts.

We expected a negative sign for this variable, because it is assumed that the lower the cost of debt, the greater the ease companies will have in the access to credit and, presumably, the greater their willingness to grant the same.

Sales Profitability, in an operational level (SP) is another important factor which allows us to analyze the willingness of companies to grant credit. This variable is given by the ratio of Operational Earnings and Total Sales.

It is assumed that this indicator should have a positive sign, since the higher the profitability, the lower the risk of insolvency, which will allow these companies to grant more trade credit to customers.

General Liquidity (GL) is also a key indicator in this study. Given by the ratio between assets and current liabilities, this indicator shows the company's short-term situation. A positive sign is expected for this, since the company's willingness to grant credit will be expected to be higher, the better its short-term situation is.

Assets Rotation (AR), given by the ratio of Total Sales/Services and Total Assets, is considered to be one of the most important variables because it is expected that the most active companies provide more credit to their customers. A positive indicator was expected.

Solvency (SOLV) is another very important ratio because it measures a company's ability to cover liabilities (Total Assets/Total Liabilities). This indicator is expected to be positive because a higher solvency should normally reflect a greater willingness to grant credit.

A positive indicator was also expected for the Gross Margin (GM), which is the ratio of (Turnover - Sales Costs)/Turnover, because it is expected that a company with a higher indicator here would be more willing to facilitate the accounts with their clients.

We expected both signals for the Credit Received by the Company (CRC) - obtained from the ratio of net accounts and total assets - because on the one hand, if the company does not have 
financial difficulties, and it does not need to resort to credit from its suppliers a negative sign can be expected. On the other hand, a positive sign could be expected when companies are in financial difficulties: when this happens the financial credibility of the company is negatively affected, their customers tend to achieve longer average payment periods, which will lead the company to strive for achieving longer average payment from their own suppliers, thus also increasing the credit they give to them.

\subsection{Research model}

To analyze the collected data, we use the methodology of panel data, based on the method of least squares, using the fixed effects model. We also use the Stata Software to analyze the data.

The model is:

$$
G C C=\beta 0+\beta 1 C D E B T+\beta 2 \mathrm{SP}+\beta 3 G L+\beta 4 A R+\beta 5 S O L V+\beta 6 G M+\beta 7 C R C+\varepsilon \text { it. }
$$

\section{Results}

With the application of the model, we come to the following Pearson correlation coefficients, divided by LC and SME's.

Table 1. Pearson Correlation Coefficients - LC

\begin{tabular}{|l|c|r|r|r|r|r|r|}
\cline { 2 - 8 } \multicolumn{1}{c|}{} & CDEBT & SP & \multicolumn{1}{c|}{ GL } & \multicolumn{1}{c|}{ AR } & SOLV & \multicolumn{1}{c|}{ GM } & \multicolumn{1}{c|}{ CRC } \\
\hline CDEBT & 1.0000 & 0.0211 & -0.0326 & -0.0197 & 0.0121 & -0.0323 & 0.4350 \\
\hline SP & & 1.0000 & 0.0200 & 0.0050 & 0.0011 & -0.0100 & 0.0056 \\
\hline GL & & & 1.0000 & -0.0120 & 0.1350 & -0.0310 & -0.0109 \\
\hline AR & & & & 1.0000 & 0.0600 & -0.0090 & 0.0020 \\
\hline SOLV & & & & & 1.0000 & -0.0564 & -0.0089 \\
\hline GM & & & & & & 1.0000 & -0.0090 \\
\hline CRC & & & & & & & 1.0000 \\
\hline
\end{tabular}

Source: self elaboration.

This way, we conclude that:

- for the SMEs analyzed (as we can see in Table 2), there is a strong correlation (0.8024) between GL and the CRC,

- there are also significant percentages of correlation (close to $50 \%$ ) between the variables CDEBT and SOLV, GL and GM.

Table 2. Pearson Correlation Coefficients - SME

\begin{tabular}{|l|c|c|c|c|c|c|r|}
\cline { 2 - 8 } \multicolumn{1}{c|}{} & CDEBT & SP & GL & AR & SOLV & GM & \multicolumn{1}{c|}{ CRC } \\
\hline CDEBT & 1.0000 & -0.0510 & -0.0120 & -0.0200 & 0.4950 & 0.0300 & -0.1400 \\
\hline SP & & 1.0000 & 0.0301 & -0.1239 & 0.2200 & 0.0289 & -0.0040 \\
\hline GL & & & 1.0000 & -0.0409 & 0.0600 & -0.4761 & 0.8024 \\
\hline
\end{tabular}




\begin{tabular}{|c|c|c|c|c|}
\hline AR & 1.0000 & 0.3069 & 0.1625 & 0.1290 \\
\hline SOLV & & 1.0000 & -0.0500 & -0.2012 \\
\hline GM & & & 1.0000 & -0.3214 \\
\hline CRC & & & & 1.0000 \\
\hline
\end{tabular}

Source: self elaboration.

Overall, it can be concluded that the model does not display autocorrelation problems, except for the variables GL and CRC, which have a strong correlation between them.

Through a descriptive statistical analysis of our sample, we can make some interesting observations.

Table 3. Descriptive Statistical Analysis

\begin{tabular}{|l|c|c|c|c|c|c|c|c|}
\cline { 2 - 9 } \multicolumn{1}{c|}{} & GCC & $\begin{array}{c}\text { CDEBT } \\
(\%)\end{array}$ & SP & GL & AR & SOLV & GM (\%) & CRC \\
\hline \multicolumn{8}{|c|}{ LC } \\
\hline Average & 0.419 & 3.901 & 0.003 & 1.490 & 1.634 & 1.806 & 67.112 & 1.200 \\
\hline Median & 0.305 & 3.100 & 0.020 & 0.991 & 1.402 & 1.451 & 71.283 & 0.190 \\
\hline Standard desviation & 0.205 & 4.237 & 1.047 & 5.409 & 6.606 & 1.309 & 26.132 & 60.359 \\
\hline \multicolumn{8}{|c|}{ SME } \\
\hline Average & 0.415 & 2.534 & -0.294 & 1.432 & 2.602 & 1.380 & 89.834 & 0.301 \\
\hline Median & 0.350 & 1.246 & 0.003 & 0.560 & 1.799 & 1.113 & 92.580 & 0.042 \\
\hline Standard Deviation & 0.281 & 3.231 & 0.890 & 4.159 & 3.051 & 1.401 & 20.150 & 0.852 \\
\hline
\end{tabular}

Source: self elaboration.

As we can see in Table 3, on average, LCs and SMEs grant nearly the same proportion of commercial credit. However, SMEs with negative sales profitability but high levels of solvency and liquidity, grant more credit than they themselves received.

Regarding LCs, these are more profitable and show higher levels than those discussed in the preceding paragraph for SMEs. However, despite the level of concession/reception of credit, the situation is contrary for that kind of company. It is worth noting that the higher value constants in the credit received by LCs, when comparing with the credit granted often justifies their development capacity: the negotiating capacity of the average payment and receipt periods are a very influential feature in the development of a company.

SMEs have a lower debt cost, although these are riskier companies. This is mainly due to their lower indebtedness.

Regarding the analysis of regressions performed, we arrived at the following values.

Table 4. Regression Results - Fixed Effects - SME

\begin{tabular}{|l|c|c|c|c|c|}
\hline \multicolumn{1}{|c|}{ Variables } & Expected Sign & Coefficient & T Statistic & P Value & \\
\hline CONST & & 0.5152 & 1.6328 & 0.1301 & \\
\hline CDEBT & - & -0.0210 & -1.3902 & 0.2014 & \\
\hline SP & + & 0.0217 & 0.4212 & 0.7013 & \\
\hline
\end{tabular}




\begin{tabular}{|l|c|c|c|c|c|}
\hline GL & + & 0.0139 & 1.6253 & 0.1101 & \\
\hline AR & + & 0.1621 & 4.7024 & 0.0001 & $* * *$ \\
\hline SOLV & + & -0.0548 & -1.0479 & 0.3015 & \\
\hline GM & + & -0.0030 & -0.5438 & 0.5095 & \\
\hline CRC & \pm & -0.3049 & -3.0689 & 0.0049 & $* * *$ \\
\hline $\mathrm{R}^{2}$ & & & 0.7734 & & \\
\hline Adjusted $\mathrm{R}^{2}$ & & & 0.6023 & & \\
\hline
\end{tabular}

Source: self elaboration.

Table 5. Regression Results - Fixed Effects - LC

\begin{tabular}{|l|c|c|c|c|c|}
\hline \multicolumn{1}{|c|}{ Variables } & Expected Sign & Coefficient & T Statistic & P Value & \\
\hline CONST & & 0.2598 & 20.1265 & 0.0080 & $* * *$ \\
\hline CDEBT & - & -0.0030 & -2.7029 & 0.0001 & $* * *$ \\
\hline SP & + & 0.0108 & 1.9907 & 0.0470 & $* *$ \\
\hline GL & + & 0.0074 & 5.5087 & 0.0001 & $* * *$ \\
\hline AR & + & 0.0051 & 5.9054 & 0.0029 & $* * *$ \\
\hline SOLV & + & -0.0039 & -11.4021 & 0.0045 & $* * *$ \\
\hline GM & + & 0.0019 & 12.5091 & 0.0075 & $* * *$ \\
\hline CRC & \pm & -0.0003 & 0.9078 & 0.5086 & \\
\hline $\mathrm{R}^{2}$ & & & 0.4239 & & \\
\hline Adjusted $\mathrm{R}^{2}$ & & & 0.2785 & & \\
\hline
\end{tabular}

Source: self elaboration.

Through Tables 4 and 5, we determine some important considerations. Namely, that in SMEs, only AR and the CRC are provided with statistical significance, influencing the dependent variable (GCC). AR appears with the expected signal (positive), and the CRC has a negative sign, which results in a contrary relationship between the credit received and granted.

In relation to LCs, all variables, except the CRC, are statistically significant, with $1 \%$ and $5 \%$. Suggesting that in general, companies with lower debt levels (CDEBT), lower risk of insolvency and bankruptcy (higher SP), lower solvency (contrary to what would be expected, as we noted in the signal), higher profitability and greater liquidity, are more willing to extend credit to customers.

Separating the analysis of LCs and SMEs permits us to conclude that, for LCs, the ability to access the capital markets is crucial to grant credit to their customers, confirming H1. However, there is no statistical evidence to validate this hypothesis in the case of SMEs.

As we have seen in the descriptive statistics table, it was possible to prove that the LCs grant trade credit to their customers at a very similar level to SMEs, therefore we cannot validate H2.

$\mathrm{H} 3$, which describes the idea of the existence of a direct and positive relationship between the gross margin and the granting of credit, is proved in the case of LCs. However, we do not have statistical evidence that enables us to weave conclusions at this level for SME.

Regarding H4, this really verified for both company sizes, proving that companies with higher assets rotation normally grant more trade credit. 
After this divided analysis of our sample, given the small size of it, we chose to consider all companies in a single sample, in order to validate our model. Thus, we consider the entry of variable Dimension (DIM), in order to identify two sets of samples.

Then, we obtained the following results:

Table 6. Regression Results - Fixed Effects - Total Sample

\begin{tabular}{|l|c|c|c|c|c|}
\hline \multicolumn{1}{|c|}{ Variables } & Expected Sign & Coefficient & T Statisctic & P Value & \\
\hline CONST & & 0.1725 & 5.0013 & 0.0001 & $* * *$ \\
\hline CDEBT & - & -0.0029 & -1.5932 & 0.0492 & $* *$ \\
\hline SP & + & 0.0160 & 2.5963 & 0.0092 & $* * *$ \\
\hline GL & + & 0.0050 & 4.9545 & 0.0050 & $* * *$ \\
\hline AR & + & 0.0029 & 6.7921 & 0.0001 & $* * *$ \\
\hline SOLV & + & -0.0283 & -10.2945 & 0.0001 & $* * *$ \\
\hline GM & + & 0.0030 & 13.4952 & 0.0020 & $* * *$ \\
\hline CRC & \pm & -0.0003 & 0.7148 & 0.5031 & \\
\hline DIM & + & 0.0264 & 2.7492 & 0.0090 & $* * *$ \\
\hline $\mathrm{R}^{2}$ & & & 0.3502 & & \\
\hline Adjusted $\mathrm{R}^{2}$ & & & 0.2101 & & \\
\hline
\end{tabular}

Source: self elaboration.

This way, we obtained results that allow us to prove the hypotheses H1, H3 and H4 we formulated earlier.

Considering our $\mathrm{H} 2$, different to what was found in the divided analysis, we validate the hypothesis here, because we obtained statistical evidence that the size of the company is related to the level of commercial credit granted by it.

\section{Conclusion}

We can draw some interesting conclusions from this study, even though we have not recorded many new conclusions on the theme, despite the time differences from other analyses. This in itself was surprising for us, because we could have expected to draw different conclusions, given the many new variable inherent in the updated database used. The firms analyzed have been influenced by a number of situations, not only the difficulty of access to credit caused by the economic crisis, but also inherent changes in the market like the average payment and receipt period policies that have occurred over time. What is more, the firms studied came from differentiated sectors and new variables were included in the study.

Another interesting aspect to be considered was, for example, the fact that large companies are the ones that most appeal to commercial credit, which is the opposite of what we would expect. These companies have greater stability and security, and we hoped that they would not resort to credit in this way; and also the fact that, in SMEs, from all the variables analyzed only the assets rotation and the credit received influence the granting of credit by them, rather than what is happening in LCs, where all variables, except the credit received, influenced the granting of credit. 
It is also to highlight that companies with greater ability to access the capital markets, higher gross margin and higher sales volume grant more trade credit than the others.

As limitations of the investigation, we can refer to the size of our sample, constituted by a very small data set, which means that it is not possible to generalize safely the existing situation. However, analyzing the market, we understand that the results we have reached will not be completely unreasonable, given the economic, financial and labor market stage that the companies have overcome.

Another of the limitations that we can point involves the analysis we did: this consisted in a static terms analysis (fixed effects). An analysis based on the data presented in dynamic panel could give us some other ideas that are not offered by this kind of analysis only.

As potential new studies to perform, and taking some of the limitations that we point to in our model, we can mention the possible inclusion of a larger number of companies in the sample, which could allow a better generalization of the conclusions reached, as well as the inclusion of other variables that have not been studied by us and, indeed, may have a significant influence on commercial lending, our variable under study.

We can also mention the possibility of data analysis by a dynamic panel, or using other analysis methods, such as interviews or case studies, which could be quite interesting.

\section{References}

Bahillo, I. (2000). El Crédito Comercial: Un Estudio Empírico con Datos Norteamericanos. Centro de estúdios monetários y financeiros (CEMFI), No. 0007.

Biais, B., Gollier, C. (1997). Trade credit and Credit rationing. The Review of Financial Studies, 10 (4), $903-937$.

Brennan, M., Maksimovic, V. e Zechner, J. (1988). Vendor Financing. The Journal of Finance, 2 (43), $1127-1141$.

Cheng, N., Pike, R. (2003). The Trade Credit Decision: Evidence of UK Firms. Managerial and Decision Economics, $24(6-7), 419-438$.

Comissão de Mercados de Valores Mobiliários (CMVM). Sistema de difusão de informação, emitentes.Ferris, S. (1981). A Transactions Theory of Trade Credit Use. The Quarterly Journal of Economics, 96 (2), 243-270.

García-Teruel, P., Martínez-Solano, P. (2010). Determinants of trade credit: A Comparative study of European SMEs. International Small Business Journal, 28 (3), 215-233.

Kashefi-Pour, E., Lasfer, M., Carapeto, M. (2010). The Determinants of Capital Structure across Firms' Sizes: The UK Main and AIM Markets Evidence. Retrieved from: http://ssrn.com/abstract=1680892 (06.05.2016).

Mian, S., Smith, C. (1992). Accounts Receivable Management Policy: Theory and Evidence. The Journal of Finance, 47 (1), 169-200.

Modigliani, F., Miller, M. (1958). The cost of capital, corporation finance, and the theory of investment. The American Economic Review, 48 (3), 261-297.

Modigliani, F., Miller, M. (1963). Corporate income taxes and the cost of capital: A correction. The American Economic Review, 53 (3), 433-443.

Mota, E. (2013). O Impacto da gestão financeira de curto prazo no desempenho das empresas. Master Dissertation in Finance, presented in Faculty of Economics, University of Porto in November, 2013.

Myers, S. (1984). The capital structure puzzle. The Journal of Finance, 39 (3), 575-592.

Nilsen, J. (2002). Trade Credit and the Bank Lending Channel. Journal of Money, Credit and Banking, 34 (1), $226-253$.

Ogawa, K., Sterken, E., Tokutsu, I. (2011). The Trade Credit Channel Revisited: Evidence from Micro Data of Japanese Small Firms. Small Business Economics, 40, 101-118.

Petersen, M., Rajan, R. (1997). Trade Credit: Theories and Evidence. The Review of Financial Studies, 10 (3), $661-691$. 
Rodríguez-Rodríguez, O. (2008). Firms as Credit Suppliers: An Empirical Study of Spanish Firms. International Journal of Managerial Finance, 4 (2), 152-173.

Schwartz, R. (1974). An Economic Model of Trade Credit. Journal of Financial and Quantitative Analysis, 12, 519-524.

Serrasqueiro, Z., Nunes, P. (2008). Determinants of capital structure: Comparison of empirical evidence from the use of different estimators. International Journal of Applied Economics, 5 (1), 14-29.

Van Der Wijst, N., Hol, S. (2002). Trade Credit in Europe. Norwegian University of Science and Technology, European Working Group on Financial Modeling (EWGFM).

Vieira, E. (2013). Determinantes da Estrutura de Capital das Empresas Portuguesas Cotadas. Revista Portuguesa e Brasileira de Gestão, 12 (1), 38-51.

Vieira, E., Novo, A. (2010). A Estrutura de Capital das PME: Evidência no Mercado Português. Revista Estudos do ISCA, 2 .

\section{Cytowanie}

dos Santos Morão Lourenço, A.J., Gonçalves Governo, A., Gonçalves Leal, A.I. (2016). The importance of commercial credit for business in Portugal. Współczesne Finanse. Teoria i Praktyka, 1 (1), 35-45. DOI: 10.18276/wf. 2016.1-04. 